\title{
Effective and Efficient Food Commodity Distribution Strategy at The Indonesia Logistics Bureau (BULOG)
}

\author{
Yusup Rachmat Hidayat ${ }^{1}$, Yuli Evitha ${ }^{2}$ \\ \{yusup.rachmat@gmail.com ${ }^{1}$,yuli.evitha@gmail.com²
}

Departement of Logistics Management, Institut Ilmu Sosial dan Manajemen Stiami, Indonesia ${ }^{1,2}$

\begin{abstract}
One of the business The Indonesia Logistics Bureau (BULOG) is logistics management of food commodities which have an important role in realizing national food security. Business activities BULOG has a commercial function and noncommercial functions or public service obligation (PSO) which is the duty from government. One of the BULOG activities that most felt by the people is the distribution of food commodities that have a large and broad influence on stability, affordability and availability of food commodities in the people. This study aims to determine the strategies used by BULOG in achieving effective and efficient food commodities distribution activities. This research was conducted with a policy research approach, with qualitative analysis, secondary data sources and explained descriptively. The results of the study show the implemented strategies by BULOG in food commodities distribution by applying the types of direct distribution channels and indirect distribution channels for their commercial business functions. Whereas for public service obligation function by applying the type of distribution channel whose system and mechanism are adjusted to the laws and government regulations, because public service obligation function are the duty from the government and use the Indonesia State Budget (APBN) which must be account to the public.
\end{abstract}

Keywords: Commercial Distribution Channel, Food Distribution Channel, NonCommercial Distribution Channel.

\section{Introduction}

The Indonesia Logistics Bureau (BULOG) is one of the Government-Owned Enterprises (BUMN) in the form of a Public Company (Perum) which has commercial and noncommercial business functions. The commercial business function is to get profits to run and develop its business, while the non-commercial business function is the duty of the government in the form of Public service obligation (PSO). One of the business sectors carried out by BULOG is managing logistics in the field of food commodities.

The logistics management of food commodity by BULOG has a large and broad influence on stability, affordability and availability of food commodities to all Indonesian people. Of all BULOG logistics business activities that are most felt and directly affected by the public are food distribution activities.

Distribution is one of the elements of logistics management activities, according to Tjiptono (2014: 295), "Distribution channels are a series of organizational participants who perform all the functions needed to deliver products / services from sellers to final buyers". 
Meanwhile according to Daryanto (2011: 63 ), "Distribution is an organizational tool that is interdependent in providing a product to be used or consumed by consumers / users".

In conducting a distribution system, BULOG certainly has a distribution strategy that can be applied simultaneously and does not interfere with each other between commercial business functions and non-commercial business functions. This distribution strategy is of course to achieve effective and efficient business operations in managing the logistics of food commodities.

According to Trisilawaty et. al. (2011), The strategy is realized by the application of company policy in dealing with six factors driving supply chain performance, namely facilities, inventory, transportation, information, resources, and prices.

"Food distribution is an efficient distribution system which is a prerequisite for ensuring that all households can obtain sufficient quantities of food and quality at all times, at affordable prices", Nainggolan (2008).

A study that has been done before about the role of distribution channels in product and service marketing, Lubis (2004), "To place an item and service in the right place, the right quality the right amount, the right price and the right time needed a distribution channel right too. If the company is wrong in choosing a distribution channel it will be able to disrupt the smooth flow of goods or also from the company into the hands of consumers ".

From the background of the problems mentioned above, a question arises about:

1. What is the distribution strategy for food commodities in BULOG which has the function of commercial and non-commercial business activities?

2. Is the distribution strategy effective and efficient for BULOG business operations that have the function of commercial and non-commercial business activities?

This study aims to identify the application of food commodity distribution strategies carried out by the Bureau of Logistics and to find out whether the strategy is effective and efficient for BULOG business operations that have the function of commercial and noncommercial business activities at once.

\section{Research Method}

Sugiyono (1999: 1) The research method is basically a scientific way to obtain data with specific purposes and uses. In conducting this research, the authors approached the Policy Research method and used qualitative data analysis. Sugiyono (Majchrzak, 1987) explains, policy research is a process of research carried out on, or analysis of basic social problems, so that findings can be recommended to decision makers to act practically in solving problems.

Data analysis in this study was carried out by qualitative analysis. Denzin and Lincoln (Moleong, 2005) explain that qualitative research is research that uses natural settings, with the intention of interpreting phenomena that occur and are carried out by involving various existing methods. With sources of data obtained secondary, which are data obtained by researchers indirectly and from studies of several journals, articles, government regulations, company data, internet, etc. which is considered relevant and related to the topic of research.

And the results of this study in the preparation and delivery or the level of exploration carried out a descriptive approach. Moleong (2008: 6) explains that descriptive research is research that describes and paints the state of the object of research at present as it is based on facts. 


\section{Result And Discussion}

From the results of the research, the function of BULOG's business activities in managing food commodities has several objectives for business functions, namely:

1. Commercial Business

2. Non-Commercial Business / Public Services Obligation (PSO).

From the various functions of business activities that are jointly managed, BULOG's distribution strategy implements a variety of different distribution channels according to the function and purpose of shipping these food commodities.

\section{Commercial Business}

BULOG, although it is one of the government-owned companies (BUMN), in its business activities still has to carry out the function of commercial business activities to seek profits to support, operate and develop the BULOG business as a whole and compete with other companies in a market mechanism.

In distributing products in the form of food commodities for its commercial business functions, BULOG conducts a distribution strategy by implementing distribution channels that generally apply and are known in various businesses and by the community. The distribution channel is another:

a. Direct Distribution Channel

b. Indirect Distribution Channel

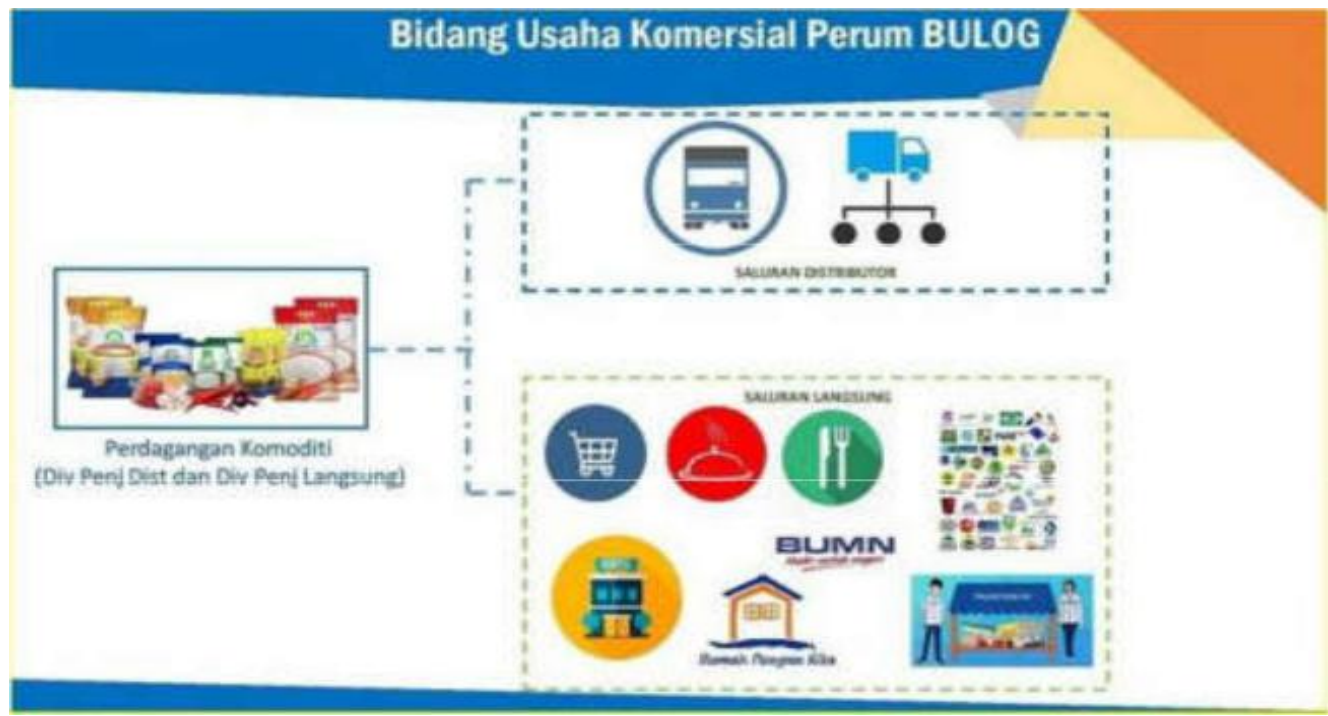

Figure 1. Distribution Channel of the BULOG Commercial Business Unit

Source:https://www.kompasiana.com/agungatv/5afb4e59cf01b475ae00def2/yuk-raih-penghasilanmelalui-program-rumah-pangan-kita-perum-bulog?page=all 


\section{a. Direct Sales Distribution Channels}

Distribution of BULOG products carried out by BULOG directly to consumers. In this case, activities are distributed and trade transactions are carried out directly between BULOG and consumers without intermediaries. The Direct sales distribution channels are carried out in various ways as follows:

1) consumers buy directly at the BULOG Mart Shop at the BULOG divorce.

2) BULOG uses cars placed at target points and;

3) BULOG through Direct Sales directly sells to consumers which they call

HOREKA (hotels, restaurants, catering), etc.

\section{b. Indirect Distribution Channel}

Product distribution carried out by BULOG indirectly to consumers through sales intermediaries. The intended intermediary for selling BULOG food commodities are distributors and BULOG partners.

Distributors are intermediaries for the sale of food commodities who act and act as agents or large traders in traditional markets and modern markets, modern retailers. Distributors get supplies from BULOG with certain quantity, quality and price and determine the return selling price according to the Highest Retail Price (HET) set by the government. Or conversely the sales brokers or distributors can buy directly into the BULOG warehouse.

Whereas the BULOG Partner is developing a direct distribution channel with a community-based Partnership Program with business guidance to become a food entrepreneur and become an agent for selling BULOG products. There are two partnership programs carried out by BULOG to the community for guidance as partners and become agents of entrepreneurs in the food sector, namely Rumah Pangan Kita (RPK), and Toko Baitul Pangan (TOBATAN).

\section{Business Non-commercial or Public Service Obligation (PSO)}

The function of non-commercial business activities is the function of business activities with the aim not to seek profit in the form of the implementation of the duties of the public services obligation (PSO) given by the government because BULOG is one of the government-owned enterprises (BUMN).

This PSO's duties activity from the government is the management of food commodities whose general purpose is to realize national food security with more specific type food commodities management is rice. The PSO activities of the government, especially the management of rice type food commodities are activities that dominate all operational activities of BULOG in the food commodity logistics management sector.

The reason the government assigns management of more specialized and large staple foods to rice-type food commodities to BULOG, is due to the following:

a. The nature of rice that is vulnerable and easily damaged.

b. Rice has uncertainty in terms of availability and price.

c. In terms of staple food needs in Indonesia, rice has a large, broad and mass level of needs.

d. As Rice is an important commodity in food security of a country. Many countries implement special food availability policies for rice to realize food security and as a national food reserve.

e. As Rice is very strategic in dealing with emergencies, disasters and food insecurity. 
The distribution of food commodities by BULOG which is the duty of the government has various programs with different goals, objectives and functions and has been regulated in accordance with applicable government laws and regulations, as well as the distribution channels also adjusted by applicable laws and regulations.

Some of the implementation of the PSO program from the government was carried out by BULOG in terms of logistics management of staple food commodities, especially rice, namely:

a. Procurement and Distribution of Bansos Rastra

b. Management of Government Rice Reserves (CBP) for activities:

1) Market Operations.

2) Handle emergencies, disasters and food insecurity.

3) Assistance and / or international cooperation and other requirements stipulated by the government.

\section{a. Procurement and Distribution of Rastra Bansos}

The program has long been known by the Indonesian people for a long time, namely rice for the poor (Raskin) and is now transformed into a Social Assistance of Rice For The Community to Prosperous (Bansos Rastra). The transformation of the government program in the form of a rice food subsidy pattern into a pattern of social assistance began to be effective in 2018. The fundamental changes and differences between the previous programs were in implementation, namely at Bansos Rastra there is no price / ransom fee to be paid by the recipient's family benefits (KPM), so that beneficiary families are expected to be more prosperous.

The distribution of Bansos Rastra is regulated through a mechanism in accordance with applicable regulations. There are technical guidelines for the implementation of prosperous rice social assistance (2018) as a general guideline for the Bansos Rastra which has been explained in relation to the pattern and mechanism of the Bansos Rastra distribution channel.

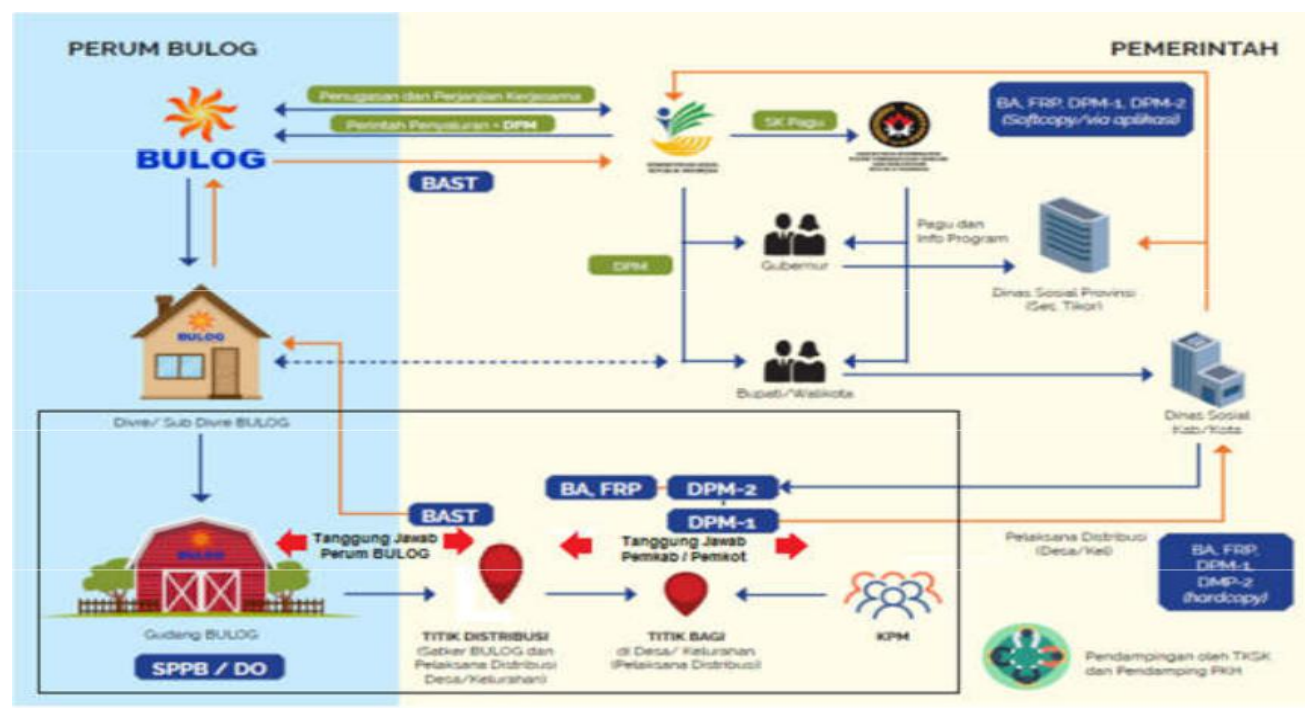


Figure 2. Distribution Mechanism for Bansos Rastra

Source: Petunjuk Teknis Bansos Rastra 2018, Kemensos RI

\section{b. Government Rice Reserves Management(CBP)}

Government Rice Reserve Management (CBP) is a PSO's duties program from the government managed by BULOG. Regulated In accordance with, Permentan (2018), about the Determination of the Amount of Government Rice Reserves, Government Rice Reserves are rice supplies that are controlled and managed by the government.

In addition, it is in accordance with Perpres (2016), about the Assignment of BULOG in the Framework of National Food Security. Government Rice Reserve Management by BULOG in the purpose and purpose of its use can be grouped among others to:

1) Market Operations

2) Handling Emergencies, Disasters and Food Insecurity,

3) Assistance and / or International Cooperation and other requirements stipulated by the government.

In each distribution of government rice reserves, different purposes and purposes have been used and the distribution channels implemented have a system and mechanism adapted to government laws and regulations.

\section{1) Market Operations}

The general principles of market operations for handling food shortages and stabilizing food prices are:

a) To prevent a surge in the increase in rice prices that can disturb the public.

b) Performed in certain areas at certain times.

c) Implemented by the merchant and related task force.

d) Using Government Rice Reserves.

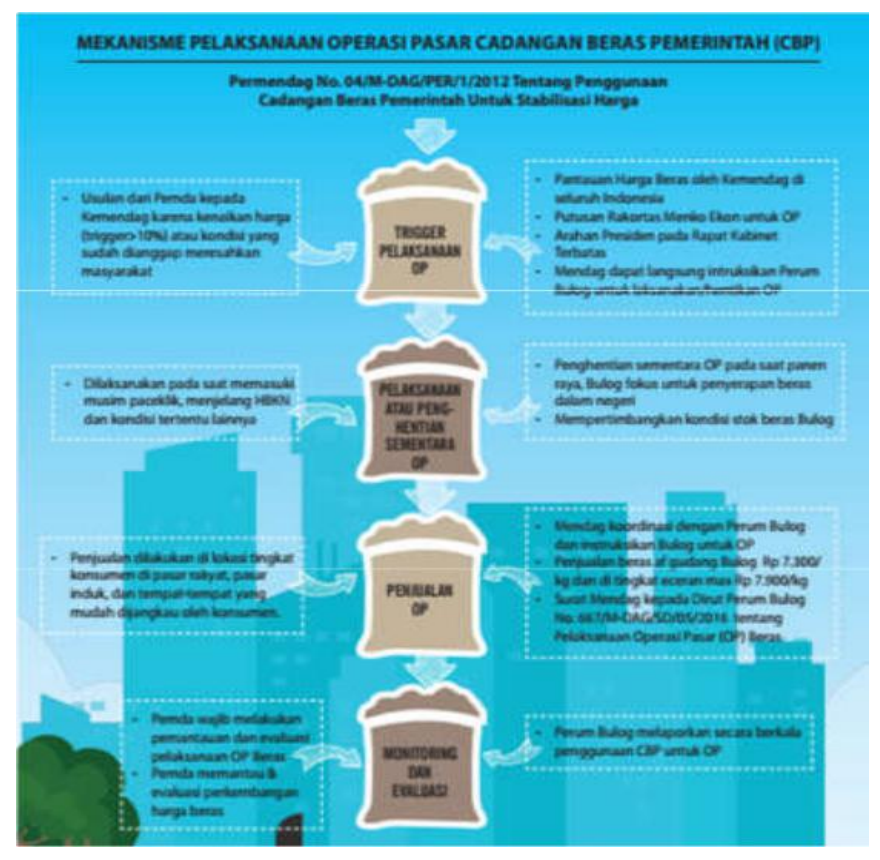


Figure 3. System and Mechanism Market Operation

Source: Buletin Vol.I.2016, Kementerian Perdagangan RI. www.kemendag.go.id

\section{2) Handling Emergencies, Disasters and Food Insecurity.}

Permensos (2012), about Procedures and Mechanisms for Distribution of Government Rice Reserves for Emergency Response Handling is the legal basis that regulates the purpose of CBP use as a response to emergencies, disasters and food insecurity. It also regulates the procedures, patterns and mechanisms for dealing with them, such as: Determination of the level of emergency response status, Duration, Amount of rice distributed, procedures for submission, submission, authority to use CBP, charging fees, monitoring, evaluation and

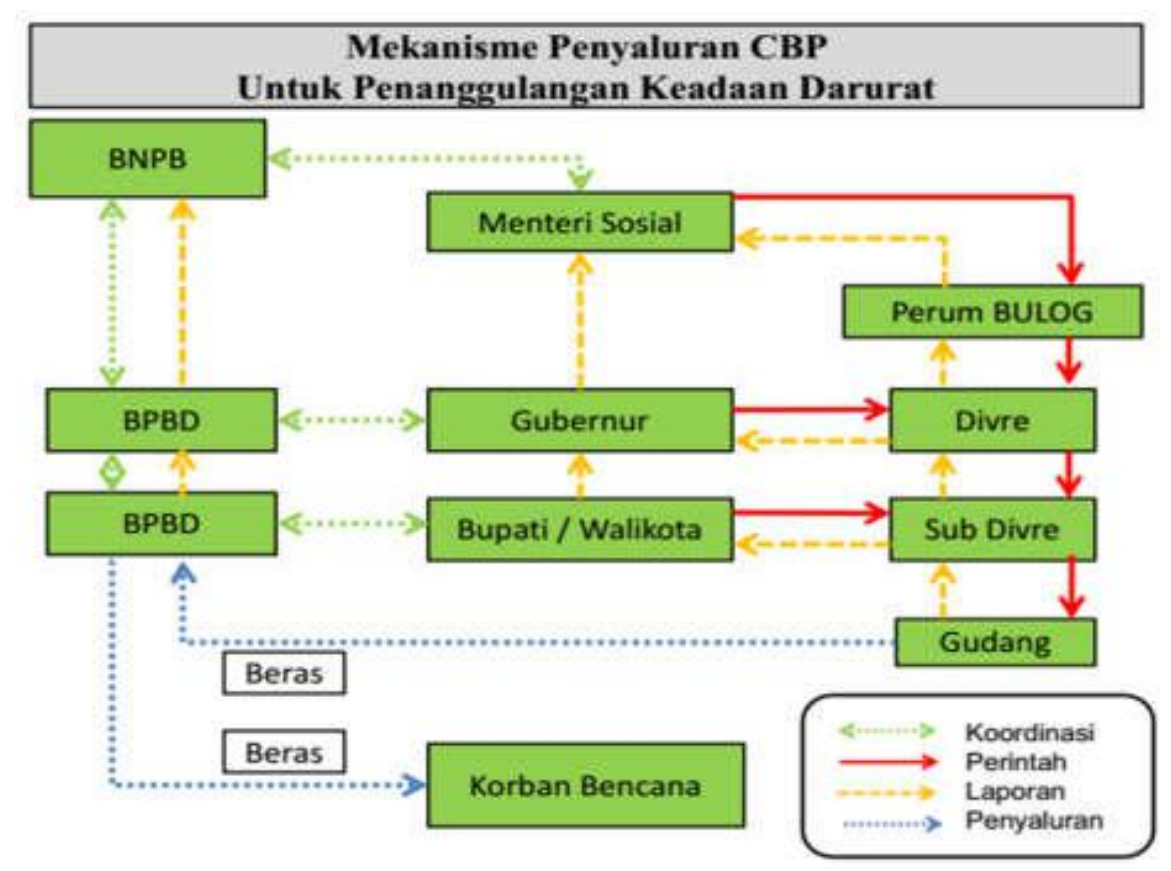

reporting.

Figure 4. System and Mechanism for the use of CBP for Emergency Management

Source: update and modification from (http://www.bulog.co.id/alur_cbp.php)

\section{3) Assistance and / or International Cooperation and other requirements stipulated by the government.}

The use of CBP as assistance to foreign countries and / or international cooperation is currently still in the mechanism of coordination of the Ministry of Foreign Affairs because until now there has been no government regulation or technical implementation instructions regarding the distribution procedures and mechanisms. 


\section{Conclusions And Suggestion}

\subsection{Conclusions}

Based on this research, it can be concluded that the effective and efficient distribution strategy of food commodities by BULOG are:

1. The distribution strategy of food commodities carried out by BULOG by applying:

a. For the functions of commercial business activities, BULOG applies Direct Distribution Channels and Indirect and Distribution Channels

b. For the functions of non-commercial business activities or Public Services Obligation (PSO), BULOG applies distribution channels based on laws and regulations.

2. For BULOG which conducts commodity food logistics management which has the function of commercial business activities and functions of non-commercial / Public Services Obligation (PSO)business activities at the same time, the distribution strategy that implemented by BULOG are distribution strategy are effective and efficient for BULOG business operations.

From this research it can be seen that a product can implement and have several distribution channels, each of which distribution channels depends on the purpose and function of the distribution of the product.

And the right distribution channel for a product depends on the purpose and function of the distribution of the product.

\subsection{Suggestion}

And based on research and conclusions, the authors suggest some recommendation for parties involved and related to BULOG business activities as following:

1. BULOG must have ability of good team work, fast and strong response in every action and decision. Because the distribution system involves many parties and a lot of coordination, which can often occur miss-communication and conflict. Moreover, BULOG in carrying out its service duties to the community has large and broad interests, so that it causes miss-communication and conflict as much as possible not to occur.

2. BULOG must have a speed of response and adaptation, for any policy changes related to the duty of public service obligations (PSO) from the government. BULOG is part of the government and is one of the A state-owned enterprise (BUMN).

\section{Reference}

[1]. Daryanto. 2011. Manajemen Pemasaran. Bandung: Pt Sarana Tutorial Nurani Sejahtera

[2]. Moleong. 2008. Metodologi Penelitian Kualitatif. Bandung: Pt Remaja Rosdakarya.

[3]. Lubis, Arlina Nurbaity. 2004. Strategi Pemasaran Dalam Persaingan Bisnis. Universitas Sumatera Utara.

[4]. Majchrzak, A. 1987. Methods For Policy Research. London: Sage Publications, Inc.

[5]. Nainggolan, Kaman. 2008. "Ketahanan Dan Stabilitas Pasokan, Permintaan Dan Harga Komoditas Pangan”. Analisis Kebijakan Pertanian. Volume 6 No. 2, Juni 2008 : 114 - 139.

[6]. Sugiyono. 1999. Metode Penelitian Bisnis. Bandung: Alfabeta. 
[7]. Tjiptono, Fandy. 2014. Pemasaran Jasa - Prinsip Penerapan Dan Penelitian. Yogyakarta: Andi Offset.

[8]. Trisilawaty, Dkk. 2014. Analisis Optimasi Rantai Pasok Beras Dan Penggunaan Gudang Di Perum Bulog Divre Dki Jakarta. Jurnal Pangan, 20 (2): 177-197.

[9]. Permensos. 2012. Peraturan Menteri Sosial Republik Indonesia, Nomor 20 Tahun 2012 Tentang Prosedur Dan Mekanisme Penyaluran Cadangan Beras Pemerintah Untuk Penanganan Tanggap Darurat. Jakarta.

[10].Permentan. 2018. Peraturan Menteri Pertanian Republik Indonesia Nomor 11/Permentan/Kn.130/4/2018 Tentang Penetapan Cadangan Jumlah Beras Pemerintah. Jakarta.

[11].Perpres. 2016. Peraturan Presiden Nomor 48 Tahun 2016 Tentang Penugasan Kepada Perum Bulog Dalam Rangka Ketahanan Pangan Nasional. Lembaran Negara Ri Tahun 2016, Nomor 105. Sekretariat Kabinet. Jakarta.

[12].Petunjuk. Teknis Pelaksanaan Bantuan Sosial Beras Sejahtera. 2018. Http://Www.Tnp2k.Go.Id/Download/16760materi\%20sosialisasi\%20bansos\%20rastra\% 202018.Pdf. Diakses 10 November 2018. 